Przegląd Badań Edukacyjnych Educational Studies Review

ISSN 1895-4308

nr 24 (1/2017), s. 59-77

ORYGINALNE

ARTYKUtY

BADAWCZE

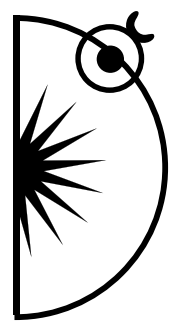

Agnieszka Dłużniewska

Akademia Pedagogiki Specjalnej im. Marii Grzegorzewskiej, Warszawa, e-mail: dluzniewskaa@gmail.com

Kamil Kuracki

Akademia Pedagogiki Specjalnej im. Marii Grzegorzewskiej, Warszawa, e-mail: kamillo17@wp.pl

Bernadetta Kosewska

Akademia Pedagogiki Specjalnej im. Marii Grzegorzewskiej, Warszawa, e-mail: bernadetta.weclawik@gmail. com

\title{
Postawy twórcze a kompetencje społeczno- emocjonalne uczniów z dysleksją i bez dysleksji w okresie wczesnej adolescencji
}

DOI: http://dx.doi.org/10.12775/PBE.2017.004

\section{Creative Attitudes and Socio-Emotional Competences of Students with Dyslexia and without Dyslexia in Early Adolescence}

\section{Abstract}

The article is an attempt to find answers to the question about the differences that exist within the competence of the socio-emotional and creative attitudes among students with dyslexia and those without dyslexia.

The tool used to investigate social skills was Social Competence Questionnaire (KKS) A. Matczak (2007), Emotional Intelligence Questionnaire (INTE) N.S. Schutte, J. M. Malouff, L. E. Hall, D. J. Haggerty, J. T. Cooper, Ch. J. Golden, L. Dornheim in Polish adaptation of A. Ciechanowicz, A Jaworowski, A. Matczak $(2000,2008)$ were used to investigate emotional intelligence. Creative attitudes were examined using - Creative Behaviour Questionnaire KANH S. Popek (2000).

The analysis of the results made it possible to extract the areas in which the functioning of both groups of students varies considerably. In relation to the above-mentioned areas, the most important differences involve social exposure, overall emotional intelligence and the 
use of emotion in the process of thinking and acting. Students with dyslexia have achieved in this case statistically lower scores than their peers without dyslexia. In the area of creative behavior students with dyslexia present a higher level of conformity and reproductive activities.

Key words: social competences, emotional intelligence, creative attitudes, dyslexia, early adolescence.

\section{Wprowadzenie}

Kompetencje społeczne warunkują jakościowy aspekt funkcjonowania człowieka $\mathrm{w}$ interakcjach $\mathrm{z}$ innymi osobami. Interakcje te dotyczą różnorodnych sytuacji począwszy od bliskich relacji między dwiema osobami (przyjaciel, małżonek itp.) poprzez funkcjonowanie w małych społecznościach (rodzina, przyjaciele, klasa szkolna, współpracownicy itp.) aż po kontakty przedstawicieli różnych kultur (Argyle, 1999). Skuteczność owych relacji, rozumiana w aspekcie subiektywnie odczuwanej satysfakcji z kontaktów interpersonalnych, zdeterminowana jest zarówno czynnikami zewnętrznymi - środowiskowymi, jak i zasobami wewnętrznymi jednostki. Co zatem należy rozumieć pod pojęciem kompetencji społecznych?

Przez kompetencję społeczną M. Argyle (1999) rozumie zdolności pozwalające na wywieranie pożądanego wpływu na innych ludzi. W swoim modelu nabywania wspomnianych umiejętności wyodrębnia cztery etapy: poszukiwanie przez jednostkę określonych celów, wykonywanie wyuczonego działania, dostrzeganie konsekwencji oraz reagowanie na zachowanie partnera lub partnerów interakcji. Syntezą zarówno przytoczonej powyżej definicji, jak i założeń modelu jest rozumienie kompetencji społecznych w ujęciu A. Matczak (2012, s. 7), według której są to „złożone umiejętności warunkujące efektywność radzenia sobie w określonego typu sytuacjach społecznych, nabywane przez jednostkę w toku treningu społecznego". Złożoność omawianych zdolności wymaga, aby wspomnieć o kilku z wielu czynników, które pozostają w bezpośredniej do nich relacji, takich jak: cechy osobowości, temperament czy inteligencja emocjonalna. Z punktu widzenia niniejszych rozważań zasadne wydaje się przybliżenie rozumienia ostatniego z przytoczonych pojęć.

Pojęcie inteligencji emocjonalnej zostało sformułowane w 1990 roku przez J. Mayera oraz P. Saloveya (Goleman, 2012). Autorzy w definicji uwzględnili zarówno zdolność do percepcji i identyfikacji emocji u siebie i innych ludzi, jak również ich rozumienie $\mathrm{i}$ analizę, a także umiejętność regulacji emocji we wspieraniu rozwoju emocjonalnego i intelektualnego oraz wspomaganiu my- 
ślenia (Salovey, Mayer, 1999). Tak rozumiana inteligencja emocjonalna zdaje się więc warunkować doskonalenie kompetencji społecznych, ale hipotetycznie może się także przyczyniać do kształtowania się postawy twórczej, wyrażającej się aktywnym stosunkiem do otaczającej rzeczywistości, przejawiającym się w jej eksploracji i przetwarzaniu (zob. Popek, 2008).

W literaturze prezentowanych jest wiele różnych stanowisk dotyczących rozumienia pojęcia twórczości. Jedne koncentrują się na aspekcie psychometrycznym, poznawczym, osobowościowym, motywacyjnym, inne na społecznym, kulturowym i historycznym, aż po takie, które charakteryzują się podejściem integrującym (Sternberg, 2001). Pomimo tego, że każde z nich bierze pod uwagę nieco inny aspekt funkcjonowania jednostki uznanej za twórczą, w każdym z nich jako cechy wyróżniające osoby twórcze wskazywane są nonkonformizm i zachowania heurystyczne (Popek, 2008).

Powyższe rozważania skłaniają do refleksji nad różnicami w kształtowaniu się kompetencji społeczno-emocjonalnych oraz postaw twórczych w odniesieniu do uczniów w okresie dorastania z uwzlędnieniem specyfiki ich indywidualnego rozwoju. Jest to tym bardziej istotne, że omawiane zdolności determinują nie tylko funkcjonowanie $\mathrm{w}$ grupie, ale również osiągnięcia szkolne dorastającego człowieka.

Dość liczną populacją, przed którą oprócz wyzwań związanych z dorastaniem stają problemy wynikające $\mathrm{z}$ procesu edukacyjnego, są uczniowie $\mathrm{z}$ dysleksją, postrzegani najczęściej właśnie przez pryzmat występujących u nich trudności w uczeniu się (Ganschow, Sparks, Schneider, 1995; Crombie, 1997, 2000; Krasowicz-Kupis, 2003; Bogdanowicz, Adryjanek, 2004; Bogdanowicz, 2006; Kamińska-Ostęp, Gulińska, 2008; Snowling, Hulme, 2011) oraz towarzyszących im problemów w społeczno-emocjonalnym funkcjonowaniu (Jaklewicz, Bogdanowicz, 1982; Burden, 2008; Terras, Thompson, Minnis, 2009; Gwernan-Jones, Burden, 2010).

Coraz częściej można jednak spotkać się z innym spojrzeniem na osoby z dysleksją, które pozwala je widzieć jako jednostki kreatywne i uzdolnione artystycznie. Istnieje kilka hipotez, za pomocą których próbuje się wyjaśnić związek między dysleksją a zdolnościami twórczymi. Jedna z nich zakłada, że kreatywność i uzdolnienia twórcze mogą być rezultatem mechanizmów kompensacyjnych mózgu. Z drugiej strony przypuszcza się, że może istnieć wspólny czynnik odpowiedzialny zarówno za występowanie dysleksji, jak i kreatywności. W tym przypadku nie należy się jednak doszukiwać związku przyczynowo-skutkowego między wymienionymi zjawiskami. Trzecia hipoteza opiera się na założeniu, że zdolności twórcze osób z dysleksją związane 
są z kompensacją funkcjonalną wczesnych niepowodzeń w zakresie cenionych przez otoczenie umiejętności szkolnych. Dzieci z dysleksją są zatem zmuszone do poszukiwania możliwości odniesienia sukcesu w innych dziedzinach niż te związane z nauką w szkole. Kolejna próba wyjaśnienia związku dysleksji z kreatywnym myśleniem i rozwiązywaniem problemów traktuje aktywowanie oryginalnych i niekonwencjonalnych strategii myślenia i zarazem radzenia sobie z niepowodzeniami jako odpowiedź na doznawaną przez uczniów ze specyficznymi trudnościami w uczeniu się frustrację, związaną z problemami w czytaniu i pisaniu. Piąta hipoteza zakłada, że związek między dysleksją a kreatywnością jest pozorny, a zdolnościami twórczymi są obdarzone na równi osoby z dysleksją, jak i bez dysleksji. Różnica dotyczy natomiast faktu, że ci, których nie dotknął problem specyficznych trudności w uczeniu się, mają szersze możliwości samorealizacji, podczas gdy możliwości dyslektyków są ograniczone do realizowania się w dziedzinach takich jak sztuka, projektowanie czy rzemiosło (Wolff, Lundberg, 2002).

Badacze zajmujący się dysleksją i jej związkiem z twórczym myśleniem i zdolnościami artystycznymi wciąż poszukują naukowego wyjaśnienia współistnienia dwóch wspomnianych zjawisk.

Everatt i in. (1999) i Everatt, Weeks i Brooks (2008) na podstawie wykonanych, w warunkach laboratoryjnych, przez osoby dorosłe $\mathrm{z}$ dysleksją oraz bez dysleksji zadań badających kreatywność potwierdzili niewielką przewagę w wykonywaniu określonych prób na korzyść osób z dysleksją. Różnic takich nie stwierdzono w odniesieniu do badanych dzieci. Wydaje się to potwierdzać tezę, że myślenie twórcze rozwija się w odpowiedzi na konieczność radzenia sobie w różnych sytuacjach życiowych. Można zatem przypuszczać, że u dzieci mechanizmy te są jeszcze $\mathrm{w}$ fazie rozwoju, natomiast dorośli dysponują już umiejętnościami radzenia sobie w sposób kreatywny z trudnościami, których przyczyną jest dysleksja.

Tafti i in. (2009, za: Martinelli, Schembri, 2014) w wyniku przeprowadzonych z wykorzystaniem Testu Kreatywnego Myślenia Torrance'a badań wykazali, że uczniowie z dysleksją osiągnęli w porównaniu do uczniów bez dysleksji znacząco wyższe wyniki w podskalach badających oryginalność oraz syntezę. Podobne wyniki, wykorzystując powyższe narzędzie, uzyskali Cockcroft i Hartgill (2004, za: Martinelli, Schembri, 2014).

Powyższych wyników, w odniesieniu do dzieci w wieku szkolnym, nie potwierdziły badania Ritchiego i in. (2013: Martinelli, Schembri, 2014), gdzie niskie wyniki w czytaniu korelowały z niskimi wynikami w kreatywnym myśleniu. Również Martinelli i Schembri (2014) w swoich badaniach nie uzyskali 
istotnych statystycznie różnic w myśleniu twórczym między uczniami z dysleksją i bez dysleksji.

Poniżej zaprezentowane wyniki badań stanowią próbę zbadania istnienia zależności między postawą twórczą a funkcjonowaniem społeczno-emocjonalnym adolescentów z dysleksją i bez dysleksji.

\section{Podstawy metodologiczne własnych badań empirycznych}

Celem niniejszych badań jest poznanie poziomu kompetencji społecznych, postaw twórczych oraz inteligencji emocjonalnej u uczniów z dysleksją i bez dysleksji, a także ustalenie związków między wymienionymi zmiennymi.

Postawionemu wyżej celowi podporządkowane zostały następujące pytania badawcze:

1. Czy, a jeśli tak, to jakie istnieją różnice między poziomem kompetencji społecznych, postaw twórczych oraz inteligencji emocjonalnej u uczniów z dysleksją i bez dysleksji?

2. Czy, a jeśli tak, to jaki istnieje związek między kompetencjami społecznymi a postawami twórczymi i odtwórczymi u uczniów z dysleksją i bez dysleksji?

3. Czy, a jeśli tak, to jaki istnieje związek między kompetencjami społecznymi a inteligencją emocjonalną u uczniów z dysleksją i bez dysleksji?

4. Czy, a jeśli tak, to jaki istnieje związek między postawami twórczymi i odtwórczymi a inteligencją emocjonalną u uczniów z dysleksją i bez dysleksji?

Metodą doboru próbki badawczej był dobór nielosowy celowy. Do organizacji czynności badawczych użyto dwóch schematów: porównawczego (Konarzewski, 2000) w odniesieniu do badanej próby uczniów z dysleksją i bez dysleksji oraz korelacyjnego (Rubacha, 2012) w odniesieniu do zmiennych mierzonych w wymienionych wyżej grupach.

Jako metody zbierania danych użyto testowania typu papier-ołówek. Analizy uzyskanych danych dokonano natomiast $\mathrm{z}$ zastosowaniem metod statystycznych - opisu statystycznego na poziomie interwałowym, a także parametrycznego testu istotności różnic (test t-Studenta) oraz istotności współczynnika korelacji r-Pearsona. Za narzędzia badawcze posłużyły trzy kwestionariusze: Kwestionariusz Kompetencji Społecznych (KKS) A. Matczak (2007), Kwestionariusz Inteligencji Emocjonalnej (INTE) N.S. Schutte, J.M. Malouff, L.E. Hall, D.J. Haggerty, J.T. Cooper, Ch.J. Golden, L. Dornheim w polskiej adaptacji A. Ciechanowicz, A. Jaworowskiej, A. Matczak $(2000,2008)$ oraz Kwestio- 
nariusz Twórczego Zachowania KANH S. Popka (2000). Rzetelność zastosowanych narzędzi mierzona współczynnikiem zgodności wewnętrznej (alfa Cronbacha) wynosi odpowiednio dla KKS $(0,93-0,95)$ (Matczak, 2012), INTE $(0,87-0,90$ dla wersji oryginalnej, $0,82-0,91$ dla polskiej wersji kwestionariusza) (Jaworowska, Matczak, 2008), KANH (0,87 - dla skali konformizm - nonkonformizm, 0,83 - dla skali zachowania algorytmiczne - zachowania heurystyczne) (Popek, 2008). Współczynniki te świadczą o wysokiej rzetelności każdego z narzędzi badawczych zastosowanych w niniejszych badaniach.

\section{Organizacja i teren badań}

Badania miały charakter pilotażowy i zostały przeprowadzone w ramach realizowanego projektu badawczego BSTM 4/15-I, finansowanego przez Akademię Pedagogiki Specjalnej im. M. Grzegorzewskiej w Warszawie.

Objęto nimi grupę 126 uczniów uczęszczających do szkół gimnazjalnych na terenie województwa lubelskiego, lubuskiego, mazowieckiego oraz warmińsko-mazurskiego. Uczniowie ci zostali podzieleni na dwie podgrupy. Do pierwszej zaliczono 63 uczniów mających opinię o specyficznych trudnościach w uczeniu się (dysleksja), natomiast do drugiej grupy zaliczono 63 uczniów bez specyficznych trudności w uczeniu się. Obie grupy były zróżnicowane pod względem płci.

\section{Analiza i interpretacja wyników badań}

W celu uzyskania odpowiedzi na pierwsze pytanie badawcze, dotyczące istnienia różnic między poziomem kompetencji społecznych, postaw twórczych oraz inteligencji emocjonalnej u uczniów z dysleksją i bez dysleksji, dokonano analizy wartości średnich wyników, jakie obie grupy uzyskały dla poszczególnych zmiennych oraz ich porównania (tab. 1, tab. 2, tab. 3).

Tabela 1. Różnice w średnich wynikach uzyskanych przez badanych dla poszczególnych zmiennych w zakresie kompetencji społecznych: KKS O - wynik ogólny, KKS I - sytuacje intymne, KKS ES - ekspozycja społeczna, KKS A - asertywność

\begin{tabular}{|c|c|c|c|c|c|c|c|}
\hline \multirow{2}{*}{ Zmienne } & \multicolumn{2}{|c|}{$\begin{array}{c}\text { Uczniowie z dysleksją } \\
(\mathrm{N}=63)\end{array}$} & $\begin{array}{c}\text { Uczniowie bez dysleksji } \\
(\mathrm{N}=63)\end{array}$ & \multirow{2}{*}{$\mathrm{t}$} & $\mathrm{df}$ & $\begin{array}{c}\text { Istotność } \\
\text { (dwustron- } \\
\text { na) }\end{array}$ \\
\cline { 2 - 8 } & $\mathrm{M}$ & $\mathrm{SD}$ & $\mathrm{M}$ & $\mathrm{SD}$ & & & \multirow{2}{*}{, 519} \\
\hline KKS 0 & 168,67 & 26,356 & 171,32 & 19,024 &, 647 & 124 & \\
\hline
\end{tabular}


Tabela 1. Różnice w średnich wynikach uzyskanych przez badanych dla poszczególnych zmiennych w zakresie kompetencji społecznych: KKS O - wynik ogólny, KKS I - sytuacje intymne, KKS ES - ekspozycja społeczna, KKS A - asertywność

\begin{tabular}{|c|c|c|c|c|c|c|c|}
\hline \multirow{2}{*}{ Zmienne } & \multicolumn{2}{|c|}{$\begin{array}{c}\text { Uczniowie } \mathrm{z} \text { dysleksją } \\
(\mathrm{N}=63)\end{array}$} & \multicolumn{2}{|c|}{$\begin{array}{c}\text { Uczniowie bez dysleksji } \\
(\mathrm{N}=63)\end{array}$} & $\mathrm{t}$ & $\mathrm{df}$ & $\begin{array}{c}\text { Istotność } \\
\text { (dwustron- } \\
\text { na) }\end{array}$ \\
\cline { 2 - 7 } & $\mathrm{M}$ & $\mathrm{SD}$ & $\mathrm{M}$ & $\mathrm{SD}$ & & &, 989 \\
\hline KKS I & 42,60 & 6,948 & 42,62 & 5,939 &, 014 & 124 &, 041 \\
\hline KKS ES & 46,51 & 8,848 & 49,44 & 7,004 & 2,065 & 124 &, 524 \\
\hline KKS A & 47,13 & 9,547 & 46,19 & 6,623 &,- 640 & 110,455 &, \\
\hline
\end{tabular}

Źródło: opracowanie własne na podstawie SPSS 23.0.

Analiza testem t-Studenta dla prób niezależnych wykazała, że średnia wyników w zakresie ekspozycji społecznej uczniów z dysleksją $(\mathrm{M}=46,51$; $\mathrm{SD}=8,848)$ jest istotnie statystycznie niższa niż średnia wyników w zakresie omawianej zmiennej dla uczniów bez dysleksji $(\mathrm{M}=49,44 ; \mathrm{SD}=7,004), \mathrm{t}(63)$ $=2,065, \mathrm{p}<0,05$. Może to świadczyć o tym, że wszystkie działania związane z koniecznością zaprezentowania się wobec innych osób są dla uczniów z dysleksją znacznie trudniejsze niż dla ich rówieśników bez specyficznych trudności w uczeniu się. Nie można wykluczyć, że jest to związane się ze wzmożoną obawą przed negatywną oceną ze strony innych.

Pozostałe średnie w zakresie ogólnego wyniku kompetencji społecznych, relacji intymnych oraz asertywności nie wskazują na istnienie istotnych statystycznie różnic.

Tabela 2. Różnice w średnich wynikach uzyskanych przez badanych dla poszczególnych zmiennych w zakresie inteligencji emocjonalnej: INTE O - wynik ogólny, INTE I (czynniki I) - zdolności do wykorzystywania emocji do wspomagania myślenia i działania, INTE II (czynnik II) - zdolności rozpoznawania emocji

\begin{tabular}{|c|c|c|c|c|c|c|c|}
\hline \multirow{2}{*}{ Zmienne } & \multicolumn{2}{|c|}{$\begin{array}{c}\text { Uczniowie z dysleksją } \\
(\mathrm{N}=63)\end{array}$} & \multicolumn{2}{|c|}{$\begin{array}{c}\text { Uczniowie bez dysleksji } \\
(\mathrm{N}=63)\end{array}$} & $\mathrm{t}$ & $\mathrm{df}$ & $\begin{array}{c}\text { Istotność } \\
\text { dwustronna }\end{array}$ \\
\cline { 2 - 6 } & $\mathrm{M}$ & $\mathrm{SD}$ & $\mathrm{M}$ & $\mathrm{SD}$ & & &, 013 \\
\hline INTE 0 & 116,98 & 18,825 & 124,37 & 13,406 & 2,535 & 112,021 &, 001 \\
\hline INTE 1 & 57,57 & 10,892 & 63,14 & 6,855 & 3,436 & 104,458 &, 477 \\
\hline INTE 2 & 42,52 & 7,195 & 43,37 & 5,985 &, 713 & 124 &, \\
\hline
\end{tabular}

Źródło: opracowanie własne na podstawie SPSS 23.0. 
Jak wynika z powyższej tabeli, analiza danych testem t-Studenta dla prób niezależnych wykazała, że średnia wyników w zakresie ogólnego wyniku inteligencji emocjonalnej uczniów z dysleksją $(\mathrm{M}=57,57$; $\mathrm{SD}=10,892)$ jest istotnie statystycznie niższa niż średnia wyników w zakresie omawianej zmiennej dla uczniów bez dysleksji ( $\mathrm{M}=63,14$; $\mathrm{SD}=6,855), \mathrm{t}(63)=3,436, \mathrm{p}<0,05$. Uczniowie z dysleksją prezentują też istotnie statystycznie niższą umiejętność do wykorzystywania emocji $(\mathrm{M}=57,57 ; \mathrm{SD}=10,892)$ jako czynnika wspomagającego myślenie i działanie niż uczniowie bez dysleksji $(\mathrm{M}=63,14 ; \mathrm{SD}=$ $6,855), \mathrm{t}(63), \mathrm{p}<0,05$. Może to mieć związek $\mathrm{z}$ doświadczaniem przez tę grupę uczniów niepowodzeń szkolnych. Sytuacje związane z koniecznością radzenia sobie $\mathrm{z}$ trudnościami $\mathrm{w}$ uczeniu się generują prawdopodobnie o wiele więcej emocji negatywnych niż pozytywnych. W tym przypadku zamiast wspomagać aktywność poznawczą, stają się czynnikiem destrukcyjnym. Uzyskane średnie w zakresie zdolności rozpoznawania emocji nie wskazują na występowanie istotnych statystycznie różnic między uczniami z dysleksją i ich rówieśnikami bez dysleksji.

Tabela 3. Różnice w średnich wynikach uzyskanych przez badanych dla poszczególnych zmiennych w zakresie postaw twórczych: $\mathrm{K}$ - konformizmu, A zachowań algorytmicznych, $\mathrm{N}$ - nonkonformizmu, $\mathrm{H}$ - zachowań heurystycznych, PO - postawy odtwórczej, PT - postawy twórczej

\begin{tabular}{|c|c|c|c|c|c|c|c|}
\hline Zmienne & \multicolumn{2}{|c|}{$\begin{array}{c}\text { Uczniowie z dysleksją } \\
(\mathrm{N}=63)\end{array}$} & $\begin{array}{c}\text { Uczniowie bez dysleksji } \\
(\mathrm{N}=63)\end{array}$ & $\mathrm{T}$ & $\mathrm{df}$ & $\begin{array}{c}\text { Istotność } \\
\text { dwustronna }\end{array}$ \\
\hline & $\mathrm{M}$ & $\mathrm{SD}$ & $\mathrm{M}$ & $\mathrm{SD}$ & & & \\
\hline K & 15,14 & 4,048 & 13,54 & 4,638 & $-2,067$ & 124 &, 041 \\
\hline $\mathrm{A}$ & 16,41 & 3,954 & 15,44 & 3,472 & $-1,460$ & 124 &, 147 \\
\hline N & 18,06 & 4,321 & 18,70 & 3,950 &, 861 & 124 &, 391 \\
\hline H & 17,78 & 4,006 & 17,44 & 4,238 &,- 454 & 124 &, 651 \\
\hline PO & 31,56 & 6,584 & 28,98 & 7,072 & $-2,112$ & 124 &, 037 \\
\hline PT & 35,84 & 7,303 & 36,14 & 7,271 &, 232 & 124 &, 817 \\
\hline
\end{tabular}

Źródło: opracowanie własne na podstawie SPSS 23.0.

W przypadku postaw twórczych analiza testem t-Studenta dla prób niezależnych wykazała, że średnia wyników $\mathrm{w}$ zakresie prezentowanej przez uczniów z dysleksją postawy konformistycznej $(\mathrm{M}=15,14 ; \mathrm{SD}=4,048)$ jest istotnie statystycznie wyższa niż średnia wyników w zakresie omawianej zmiennej dla uczniów bez dysleksji $(\mathrm{M}=13,54$; $\mathrm{SD}=4,638), \mathrm{t}(63)=-2,067$, $\mathrm{p}<0,05$. Można zatem przypuszczać, iż uczniowie z dysleksją częściej ulegają 
wpływom otoczenia, poszukują grup odniesienia, przyjmują a priori ideologię grupy za własną. Prezentują też istotny statystycznie wyższy poziom postawy odtwórczej $(\mathrm{M}=31,56 ; \mathrm{SD}=6,584)$ niż uczniowie bez dysleksji $(\mathrm{M}=28,98$; $\mathrm{SD}=7,072), \mathrm{t}(63)=-2,112, \mathrm{p}<0,05$. Nasuwa się więc wniosek, że inspiracją do ich działań twórczych stają się dzieła już istniejące.

Szukając odpowiedzi na drugi z postawionych problemów badawczych, dokonano analizy korelacji między kompetencjami społecznymi a postawami twórczymi zarówno w grupie uczniów z dysleksją, jak i bez dysleksji (tab. 4).

Tabela 4. Korelacje (r-Pearsona) zmiennych z zakresu kompetencji społecznych (KKS O - wynik ogólny, KKS I - sytuacje intymne, KKS ES - ekspozycja społeczna, KKS A - asertywność) i zmiennych w zakresie postaw twórczych ( $\mathrm{K}$ - konformizmu, A - zachowań algorytmicznych, $\mathrm{N}$ - nonkonformizmu, $\mathrm{H}$ - zachowań heurystycznych, PO - postawy odtwórczej, PT - postawy twórczej) w grupie uczniów z dysleksją ( $\mathrm{N}=63)$ i bez dysleksji $(\mathrm{N}=63)$

\begin{tabular}{|c|c|c|c|c|c|c|}
\hline Grupy & \multicolumn{2}{|c|}{ Zmienne } & KKS 0 & KKS I & KKS ES & KKS A \\
\hline \multirow{2}{*}{$\begin{array}{l}\text { Uczniowie } \\
\text { z dysleksją }\end{array}$} & \multirow{4}{*}{ K } & $\mathrm{R}$ &,- 072 & ,067 &,- 044 &,- 096 \\
\hline & & $P$ &, 576 & 600 & ,730 & ,452 \\
\hline \multirow{2}{*}{$\begin{array}{l}\text { Uczniowie } \\
\text { bez dysleksji }\end{array}$} & & $\mathrm{R}$ & $-0,164$ &,- 0137 &,$- 276^{*}$ &, 052 \\
\hline & & $P$ & ,200 & 284 & ,029 & ,687 \\
\hline \multirow{2}{*}{$\begin{array}{l}\text { Uczniowie } \\
\text { z dysleksją }\end{array}$} & \multirow{4}{*}{ A } & $\mathrm{R}$ & ,-184 &,- 129 &,- 245 &,- 020 \\
\hline & & $P$ & 149 & ,312 & ,053 & 877 \\
\hline \multirow{2}{*}{$\begin{array}{l}\text { Uczniowie } \\
\text { bez dysleksji }\end{array}$} & & $\mathrm{R}$ & ,061 &, 035 &,- 020 & 139 \\
\hline & & $P$ & ,634 & ,786 & 877 & 278 \\
\hline \multirow{2}{*}{$\begin{array}{l}\text { Uczniowie } \\
\text { z dysleksją }\end{array}$} & \multirow{4}{*}{$\mathrm{N}$} & $\mathrm{R}$ &, $427^{\star *}$ & ,291* &, $379^{* *}$ &, 428 \\
\hline & & $P$ & , 000 & ,020 & ,002 &, 000 \\
\hline \multirow{2}{*}{$\begin{array}{l}\text { Uczniowie } \\
\text { bez dysleksji }\end{array}$} & & $\mathrm{R}$ & ,245 & ,293* &, 034 & ,305* \\
\hline & & $P$ & ,053 &, 020 & ,791 &, 015 \\
\hline \multirow{2}{*}{$\begin{array}{l}\text { Uczniowie } \\
\text { z dysleksją }\end{array}$} & \multirow{4}{*}{$\mathrm{H}$} & $\mathrm{R}$ &, $337^{\star \star}$ &, $266^{*}$ & $379^{* *}$ & $428^{* *}$ \\
\hline & & $P$ & ,007 & ,035 &, 002 &, 000 \\
\hline \multirow{2}{*}{$\begin{array}{l}\text { Uczniowie } \\
\text { bez dysleksji }\end{array}$} & & $\mathrm{R}$ & ,216 & ,225 & , 149 &, 095 \\
\hline & & $P$ & ,089 & ,076 & 243 & ,461 \\
\hline \multirow{2}{*}{$\begin{array}{l}\text { Uczniowie } \\
\text { z dysleksją }\end{array}$} & \multirow{4}{*}{ PO } & $\mathrm{R}$ & ,007 &,- 020 &,- 039 &, 024 \\
\hline & & $P$ & 954 & 873 & ,760 & 852 \\
\hline \multirow{2}{*}{$\begin{array}{l}\text { Uczniowie } \\
\text { bez dysleksji }\end{array}$} & & $\mathrm{R}$ &,- 198 &,- 153 & $-301^{*}$ &, 024 \\
\hline & & $P$ & 120 & ,230 & ,017 & 851 \\
\hline
\end{tabular}


Tabela 4. Korelacje (r-Pearsona) zmiennych z zakresu kompetencji społecznych (KKS O - wynik ogólny, KKS I - sytuacje intymne, KKS ES - ekspozycja społeczna, KKS A - asertywność) i zmiennych w zakresie postaw twórczych (K - konformizmu, A - zachowań algorytmicznych, N - nonkonformizmu, $\mathrm{H}$ - zachowań heurystycznych, PO - postawy odtwórczej, PT - postawy twórczej) w grupie uczniów z dysleksją $(\mathrm{N}=63)$ i bez dysleksji $(\mathrm{N}=63)$

\begin{tabular}{|c|c|c|c|c|c|c|}
\hline \multicolumn{1}{|c|}{ Grupy } & \multicolumn{2}{|c|}{ Zmienne } & KKS 0 & KKS I & KKS ES & KKS A \\
\hline \multirow{2}{*}{$\begin{array}{l}\text { Uczniowie } \\
\text { Z dysleksją }\end{array}$} & \multirow{2}{*}{ PT } & $\mathrm{R}$ &, $437^{* *}$ &, $318^{*}$ &, $384^{* *}$ &, $448^{* *}$ \\
\cline { 3 - 7 } $\begin{array}{l}\text { Uczniowie } \\
\text { bez dysleksji }\end{array}$ & & $\mathrm{P}$ &, 000 &, 011 &, 002 &, 000 \\
\cline { 3 - 7 } & & $\mathrm{R}$ &, $259^{*}$ &, $291^{*}$ &, 105 &, 221 \\
\cline { 3 - 7 } & & $\mathrm{P}$ &, 040 &, 021 &, 411 &, 082 \\
\hline
\end{tabular}

** Korelacja istotna na poziomie 0.01 (dwustronna)

* Korelacja istotna na poziomie 0.05 (dwustronna)

Źródło: opracowanie własne na podstawie SPSS 23.0.

Analiza powyższych wyników pozwala zaobserwować różnice występujące w korelacjach między kompetencjami społecznymi a postawą twórczą w porównywanych grupach uczniów. Nietrudno zauważyć, że istnieje znacznie więcej związków między poszczególnymi aspektami prezentowanych postaw a zmiennymi wchodzącymi w zakres kompetencji społecznych u uczniów z dysleksją niż w grupie uczniów bez dysleksji. W grupie uczniów ze specyficznymi trudnościami w uczeniu się występują korelacje dodatnie o słabym lub umiarkowanym nasileniu między nonkonformizmem a ogólnym poziomem kompetencji społecznych, $\mathrm{r}=0,43$; $\mathrm{p}<0,01$, nonkonformizmem a radzeniem sobie w sytuacjach relacji intymnych $\mathrm{r}=0,29 ; \mathrm{p}<0,05$ oraz nonkonformizmem a ekspozycją społeczną $\mathrm{r}=0,38 ; \mathrm{p}<0,01$. Oznacza to, że im wyższe kompetencje społeczne posiadają uczniowie z dysleksją, tym krytyczniej potrafią ustosunkować się do postaw niezgodnych z ich własnym systemem wartości czy przekonaniami. Pozwala to zapewne postrzegać uczniów z dysleksją jako bardziej niezależnych, polegających na własnym zdaniu i konsekwentnych w działaniu. Nie pozostaje to prawdopodobnie bez wpływu na kształtowanie się obrazu samego siebie i poczucia własnej skuteczności. Stąd też można zakładać, iż kształtowanie kompetencji społecznych w opisywanej grupie w ramach działań profilaktyczno-wychowawczych będzie stwarzać szansę na rozwój charakterologicznego wymiaru postaw twórczych.

W grupie uczniów bez dysleksji korelacje istotne statystycznie występują jedynie między nonkonformizmem a wchodzeniem w sytuacje relacji intymnych $\mathrm{r}=0,29 ; \mathrm{p}<0,05$ oraz nonkonformizmem a asertywnością $\mathrm{r}=0,3 ; \mathrm{p}<0,05$. 
Kolejna grupa związków dotyczy zachowań heurystycznych i kompetencji społecznych. W przypadku uczniów z dysleksją istnieją istotne statystycznie dodatnie korelacje od słabego do umiarkowanego stopnia nasilenia między postawami heurystycznymi a kompetencjami społecznymi $r=0,34 ; p<0,01$, postawami heurystycznymi a radzeniem sobie w sytuacjach relacji intymnych $\mathrm{r}=0,27 ; \mathrm{p}<0,01$, postawami heurystycznymi a ekspozycją społeczną $\mathrm{r}=0,38$; $\mathrm{p}<0,01$ oraz postawami heurystycznymi a asertywnością $\mathrm{r}=0,43 ; \mathrm{p}<0,01$.

Powyższe związki pozwalają wnioskować, że im wyższy poziom kompetencji społecznych prezentują uczniowie z dysleksją, tym wyższa jest ich zdolność do refleksyjności, samodzielnej aktywności w myśleniu i działaniu oraz elastyczności intelektualnej.

W omawianym powyżej obszarze nie zanotowano korelacji w odniesieniu do badanej grupy uczniów bez dysleksji.

W grupie uczniów z dysleksją występują też związki między kompetencjami społecznymi a postawą twórczą. Wszystkie z występujących korelacji są dodatnie, a siła związku waha się od słabej do umiarkowanej. Analiza danych wskazuje, że istnieje istotna statystycznie korelacja między postawą twórczą a kompetencjami społecznymi $\mathrm{r}=0,44 ; \mathrm{p}<0,01$, postawą twórczą a umiejętnością nawiązywania i podtrzymywania relacji intymnych $\mathrm{r}=0,32 ; \mathrm{p}<0,05$, postawą twórczą a radzeniem sobie w sytuacjach ekspozycji społecznej $r=0,38$; $\mathrm{p}<0,01$ oraz postawą twórczą a asertywnością $\mathrm{r}=0,45 ; \mathrm{p}<0,01$. Im zatem wyższy poziom kompetencji społecznych, tym bardziej twórczą postawę prezentują uczniowie $z$ dysleksją.

Nieco inaczej związki te przedstawiają się w grupie uczniów, u których nie stwierdzono dysleksji. W tym przypadku istnieje dodatni, istotny statystycznie, słaby związek między postawą twórczą a kompetencjami społecznymi $\mathrm{r}=0,26 ; \mathrm{p}<0,05$ oraz postawą twórczą a relacjami intymnymi $\mathrm{r}=0,3 ; \mathrm{p}<0,05$. Tym samym można przypuszczać, iż zarówno poznawczy, jak i osobowościowy potencjał twórczy u uczniów bez specyficznych trudności w uczeniu się nie musi stanowić istotnego czynnika wspomagającego proces radzenia sobie w sytuacjach wymagających elastyczności zachowania, umiejętności wyrażania opinii zgodnie z własnymi przekonaniami i potrzebami oraz odporności na ocenę innych.

W przypadku uczniów bez dysleksji występują ponadto dwa rodzaje związków, które nie są obecne w grupie uczniów z dysleksją. Mowa tu o istnieniu ujemnej, słabej, statystycznie istotnej korelacji między konformizmem a ekspozycją społeczną $r=-0,27 ; p<0,05$ oraz ujemnej, słabej, istotnej statystycznie korelacji między postawą odtwórczą a ekspozycją społeczną $r=-0,3 ; p<0,05$. Oznacza to, że niskim kompetencjom w zakresie radzenia sobie w sytuacjach relacji społecz- 
nych odpowiada wyższy poziom charakterystycznego dla postaw odtwórczych konformizmu przejawiającego się uległością, pasywnością i brakiem samodzielności oraz wyższym poziomem sztywności w myśleniu i działaniu.

Badania miały też na celu ustalenie związku między kompetencjami społecznymi a inteligencją emocjonalną u uczniów z dysleksją i bez dysleksji (tab. 5).

Tabela 5. Korelacje (r-Pearsona) zmiennych z zakresu kompetencji społecznych (KKS O - wynik ogólny, KKS I - sytuacje intymne, KKS ES - ekspozycja społeczna, KKS A - asertywność) i zmiennych w zakresie inteligencji emocjonalnej ((INTE O - wynik ogólny, INTE I (czynniki I) - zdolności do wykorzystywania emocji do wspomagania myślenia i działania, INTE II (czynnik II) - zdolności rozpoznawania emocji) w grupie uczniów z dysleksją $(\mathrm{N}=63)$ i bez dysleksji $(\mathrm{N}=63)$

\begin{tabular}{|c|c|c|c|c|c|c|}
\hline Grupy & \multicolumn{2}{|c|}{ Zmienne } & KKS 0 & KKS I & KKS ES & KKS A \\
\hline \multirow{2}{*}{$\begin{array}{l}\text { Uczniowie } \\
\text { z dysleksją }\end{array}$} & \multirow{4}{*}{ INTE 0} & $r$ & ,064 & ,029 & , 169 &,- 012 \\
\hline & & $p$ & 617 & ,822 & , 186 & ,926 \\
\hline \multirow{2}{*}{$\begin{array}{l}\text { Uczniowie } \\
\text { bez dysleksji }\end{array}$} & & $r$ &, $365^{* *}$ &, $417^{\star *}$ & ,300* & ,078 \\
\hline & & $p$ & ,003 & ,001 & ,017 & ,543 \\
\hline \multirow{2}{*}{$\begin{array}{l}\text { Uczniowie } \\
\text { z dysleksją }\end{array}$} & \multirow{4}{*}{ INTE I } & $r$ & 080 &,- 022 & 198 & ,031 \\
\hline & & $p$ & ,534 & ,862 & 119 & ,808 \\
\hline \multirow{2}{*}{$\begin{array}{l}\text { Uczniowie } \\
\text { bez dysleksji }\end{array}$} & & $r$ &, $316^{*}$ &, $447^{\star *}$ & 161 & ,064 \\
\hline & & $\mathrm{p}$ & ,012 & ,000 & 208 & ,616 \\
\hline \multirow{2}{*}{$\begin{array}{l}\text { Uczniowie } \\
\text { z dysleksją }\end{array}$} & \multirow{4}{*}{ INTE II } & $r$ & ,084 & ,124 & , 105 & ,033 \\
\hline & & $p$ & ,513 & 333 & ,411 & ,800 \\
\hline \multirow{2}{*}{$\begin{array}{l}\text { Uczniowie } \\
\text { bez dysleksji }\end{array}$} & & $r$ &, $330^{* *}$ &, $278^{*}$ &, $330^{* *}$ & 141 \\
\hline & & $p$ & ,008 & ,027 & ,008 & 272 \\
\hline
\end{tabular}

** Korelacja istotna na poziomie 0.01 (dwustronna)

* Korelacja istotna na poziomie 0.05 (dwustronna)

Źródło: opracowanie własne na podstawie SPSS 23.0.

Jak wynika z danych zawartych w powyższej tabeli, w grupie uczniów bez dysleksji istnieje umiarkowana korelacja dodatnia między kompetencjami społecznymi a inteligencją emocjonalną $\mathrm{r}=0,36 ; \mathrm{p}<0,01$ oraz umiarkowana korelacja dodatnia między inteligencją emocjonalną a kompetencjami niezbędnymi w sytuacjach nawiązywania bliskiego kontaktu interpersonalnego $r=0,42$, $\mathrm{p}<0,01$ i słaba korelacja dodatnia między inteligencją emocjonalną a ekspozycją społeczną $r=0,3 ; p<0,05$. Oznacza to, że im wyższym poziomem kompetencji społecznych dysponują uczniowie bez dysleksji, tym wyższym charakte- 
ryzują się poziomem inteligencji emocjonalnej i lepiej radzą sobie w sytuacjach intymnych, a także sytuacjach ekspozycji społecznej. W przypadku omawianej grupy istnieją ponadto korelacje między umiejętnością wykorzystywania emocji jako czynnika wspomagającego myślenie i działanie a kompetencjami społecznymi $r=0,32 ; p<0,05$ oraz między radzeniem sobie w sytuacjach relacji intymnych a zdolnością wykorzystywania emocji do działania i myślenia $\mathrm{r}=0,45 ; \mathrm{p}<0,01$. Są to korelacje o umiarkowanej sile związku. Ostatnia $\mathrm{z}$ analizowanych korelacji dotyczy zdolności rozpoznawania emocji a odpowiednio: kompetencji społecznych $\mathrm{r}=0,33 ; \mathrm{p}<0,01$, radzenia sobie w sytuacjach intymnych $r=0,28 ; p<0,05$ oraz ekspozycji społecznej $r=0,33 ; p<0,01$.

Istotnych statystycznie związków między kompetencjami społecznymi a inteligencją emocjonalną nie stwierdza się natomiast w przypadku uczniów $\mathrm{z}$ dysleksją.

Uzyskane wyniki pozwalają sądzić, iż uczniowie ci w sytuacjach społecznych w większym stopniu aktywują inne niż emocjonalne zdolności służące wspomaganiu efektywnego radzenia sobie $\mathrm{w}$ relacjach $\mathrm{z}$ innymi, istotnego $\mathrm{z}$ punktu widzenia funkcjonowania $\mathrm{w}$ środowisku szkolnym. W związku z brakiem istotnych zależności pomiędzy kompetencjami społecznymi a zdolnościami postrzegania, rozumienia i wykorzystywania w działaniu emocji własnych oraz innych ludzi można także przypuszczać, iż u uczniów ze specyficznymi trudnościami w uczeniu się istnieje większe prawdopodobieństwo wystąpienia trudności adaptacyjnych.

Na pytanie o związek między postawami twórczymi a inteligencją emocjonalną u uczniów z dysleksją i bez dysleksji pozwala odpowiedzieć dokonanie analizy danych zamieszczonych w tabeli 6 .

Tabela 6. Korelacje (r-Pearsona) zmiennych z zakresu inteligencji emocjonalnej (INTE O - wynik ogólny, INTE I (czynniki I) - zdolności do wykorzystywania emocji do wspomagania myślenia i działania, INTE II (czynnik II) - zdolności rozpoznawania emocji) i zmiennych w zakresie postaw twórczych ( $\mathrm{K}$ - konformizmu, A - zachowań algorytmicznych, N- nonkonformizmu, $\mathrm{H}$ - zachowań heurystycznych, PO - postawy odtwórczej, PT - postawy twórczej) w grupie uczniów z dysleksją $(\mathrm{N}=63)$ i bez dysleksji $(\mathrm{N}=63)$

\begin{tabular}{|c|c|c|c|c|c|}
\hline Grupy & \multicolumn{2}{|c|}{ Zmienne } & INTE 0 & INTE I & INTE II \\
\hline \multirow{2}{*}{$\begin{array}{l}\text { Uczniowie } \\
\text { z dysleksją }\end{array}$} & \multirow{4}{*}{$\mathrm{K}$} & $\mathrm{R}$ & ,243 &, $273^{*}$ & 104 \\
\hline & & $P$ & ,055 & ,030 & ,416 \\
\hline \multirow{2}{*}{$\begin{array}{l}\text { Uczniowie } \\
\text { bez dysleksji }\end{array}$} & & $\mathrm{R}$ &,- 002 &,- 040 & 148 \\
\hline & & $P$ & ,985 & ,756 & 247 \\
\hline
\end{tabular}


Tabela 6. Korelacje (r-Pearsona) zmiennych z zakresu inteligencji emocjonalnej (INTE O - wynik ogólny, INTE I (czynniki I) - zdolności do wykorzystywania emocji do wspomagania myślenia i działania, INTE II (czynnik II) - zdolności rozpoznawania emocji) i zmiennych w zakresie postaw twórczych ( $\mathrm{K}$ - konformizmu, A - zachowań algorytmicznych, N- nonkonformizmu, $\mathrm{H}$ - zachowań heurystycznych, PO - postawy odtwórczej, PT - postawy twórczej) w grupie uczniów z dysleksją $(\mathrm{N}=63)$ i bez dysleksji $(\mathrm{N}=63)$

\begin{tabular}{|c|c|c|c|c|c|}
\hline Grupy & \multicolumn{2}{|c|}{ Zmienne } & INTE 0 & INTE I & INTE II \\
\hline \multirow{2}{*}{$\begin{array}{l}\text { Uczniowie } \\
\text { z dysleksją }\end{array}$} & \multirow{4}{*}{$A$} & $\mathrm{R}$ & ,057 & , 103 &,- 023 \\
\hline & & $P$ & ,658 & ,420 & ,858 \\
\hline \multirow{2}{*}{$\begin{array}{l}\text { Uczniowie } \\
\text { bez dysleksji }\end{array}$} & & $\mathrm{R}$ &,- 018 & -,012 &, 022 \\
\hline & & $P$ & 890 & ,924 & ,867 \\
\hline Uczniowie & \multirow{4}{*}{$\mathrm{N}$} & $R$ & ,057 &, 114 &,- 021 \\
\hline z dysleksją & & $P$ & ,658 & ,372 &, 868 \\
\hline \multirow{2}{*}{$\begin{array}{c}\text { Uczniowie } \\
\text { bez dysleksji }\end{array}$} & & $\mathrm{R}$ & $340^{*}$ & $326^{* *}$ &, $262^{*}$ \\
\hline & & $P$ & ,006 & ,009 & ,038 \\
\hline \multirow{2}{*}{$\begin{array}{l}\text { Uczniowie } \\
\text { z dysleksją }\end{array}$} & \multirow{4}{*}{$\mathrm{H}$} & $\mathrm{R}$ & ,023 & ,030 & ,054 \\
\hline & & $P$ &, 858 & 814 & ,672 \\
\hline \multirow{2}{*}{$\begin{array}{l}\text { Uczniowie } \\
\text { bez dysleksji }\end{array}$} & & $\mathrm{R}$ &, $532^{\star *}$ &, $454^{* *}$ &, $460^{* *}$ \\
\hline & & $\mathrm{P}$ &, 000 &, 000 &, 000 \\
\hline \multirow{2}{*}{$\begin{array}{l}\text { Uczniowie } \\
\text { z dysleksją }\end{array}$} & \multirow{4}{*}{ PO } & $\mathrm{R}$ & , 184 & ,230 &, 050 \\
\hline & & $P$ & 149 & 070 & ,696 \\
\hline \multirow{2}{*}{$\begin{array}{c}\text { Uczniowie } \\
\text { bez dysleksji }\end{array}$} & & $\mathrm{R}$ &,- 010 & -,032 & 108 \\
\hline & & $\mathrm{P}$ & ,936 & 802 & 401 \\
\hline \multirow{2}{*}{$\begin{array}{l}\text { Uczniowie } \\
\text { z dysleksją }\end{array}$} & \multirow{4}{*}{ PT } & $\mathrm{R}$ &, 046 & ,084 & 017 \\
\hline & & $P$ & ,718 & ,511 & ,893 \\
\hline \multirow{2}{*}{$\begin{array}{l}\text { Uczniowie } \\
\text { bez dysleksji }\end{array}$} & & $r$ &, $494^{* *}$ &, $442^{* *}$ & $410^{* *}$ \\
\hline & & $\mathrm{p}$ &, 000 & ,000 & ,001 \\
\hline
\end{tabular}

** Korelacja istotna na poziomie 0.01 (dwustronna)

${ }^{*}$ Korelacja istotna na poziomie 0.05 (dwustronna)

Źródło: opracowanie własne na podstawie SPSS 23.0.

Podobnie jak w poprzednich przypadkach, również w zakresie korelacji między postawami twórczymi a inteligencją emocjonalną widoczne są różnice między badanymi grupami uczniów: z dysleksją oraz bez dysleksji. W odniesieniu do uczniów ze specyficznymi trudnościami w uczeniu się jedyna korelacja, jaka zachodzi, dotyczy istotnego statystycznie związku dodatniego, słabego, 
między zachowaniami konformistycznymi a zdolnością do wykorzystywania emocji jako czynnika wspomagania myślenia i działania. Zatem wyższemu poziomowi uległości, niesamodzielności i stereotypowości w zachowaniu będzie towarzyszył wyższy poziom wykorzystania emocji w różnych rodzajach aktywności mającej na celu rozwiązanie problemu. Może to wynikać z niskiego poczucia wartości oraz chęci zrzucenia odpowiedzialności za skutki podjętych działań.

Nieco inaczej rzecz się przedstawia w przypadku uczniów bez dysleksji, gdzie obserwujemy istnienie dodatnich, istotnych statystycznie korelacji między zachowaniami nonkonformistycznymi a ogólnym poziomem inteligencji emocjonalnej $r=0,34 ; p<0,05$, zachowaniami nonkonformistycznymi a wykorzystywaniem emocji jako czynnika wspomagającego proces myślenia i działania $\mathrm{r}=0,33 ; \mathrm{p}<0,01$ oraz zachowaniami nonkonformistycznymi a zdolnością rozpoznawania emocji $r=0,26 ; p<0,05$. W przypadku zatem uczniów bez dysleksji wraz ze wzrostem poziomu inteligencji emocjonalnej wzrasta również częstość prezentowania postawy niezależności, oryginalności oraz otwartości, charakterystycznych dla jednostek twórczych.

Druga grupa korelacji dotyczy dodatnich, istotnych statystycznie umiarkowanych lub silnych związków między zachowaniami heurystycznymi a inteligencją emocjonalną $r=0,53 ; p<0,01$, zachowaniami heurystycznymi a umiejętnością wykorzystywania emocji do myślenia i działania $r=0,45$; $\mathrm{p}<0,01$ oraz zachowaniami heurystycznymi a zdolnością rozpoznawania emocji $\mathrm{r}=0,46 ; \mathrm{p}<0,01$. W tym przypadku im wyższy poziom inteligencji emocjonalnej, tym silniejsze dążenie do twórczej eksploracji otoczenia, wynikające z większej aktywności poznawczej i elastyczności intelektualnej. Co więcej, wraz ze wzrostem poziomu inteligencji emocjonalnej wzrasta $\mathrm{w}$ opisywanej grupie prezentowany przez uczniów poziom refleksyjności oraz myślenia dywergencyjnego.

Ostatnie występujące w badanej grupie uczniów bez dysleksji związki dotyczą ogólnego poziomu postaw twórczych i inteligencji emocjonalnej. Są to korelacje istotne statystycznie, dodatnie, o umiarkowanej sile zachodzące między postawą twórczą a inteligencją emocjonalną $\mathrm{r}=0,49 ; \mathrm{p}<0,01$, postawą twórczą a wykorzystaniem emocji do myślenia i działania $r=0,44 ; p<0,01$ oraz postawą twórczą a zdolnością do rozpoznawaniem emocji $\mathrm{r}=0,41 ; \mathrm{p}<0,01$. Wyniki pozwalają wnioskować, że wraz ze wzrostem inteligencji emocjonalnej wzrastają również zachowania twórcze uczniów bez specyficznych trudności w uczeniu się. Inteligencja emocjonalna wydaje się zatem jednym z ważnych stymulatorów twórczości zarówno w sferze poznawczej, jak i charakterologicznej. 


\section{Podsumowanie i dyskusja}

Wyniki powyższych badań pozwoliły wyodrębnić obszary funkcjonowania społeczno-emocjonalnego oraz zachowań twórczych, w których występują istotne statystycznie różnice między uczniami z dysleksją oraz bez dysleksji.

Okazuje się, że w zakresie kompetencji społeczno-emocjonalnych uczniowie z dysleksją osiągnęli znacząco niższe wyniki w odniesieniu do ekspozycji społecznej, ogólnej inteligencji emocjonalnej oraz wykorzystania emocji w procesie myślenia i działania. Można zatem wnioskować, że na kształtowanie się kompetencji społeczno-emocjonalnych mogą mieć wpływ sytuacje szkolne, kiedy to prezentowanie swoich umiejętności w obecności innych staje się dla uczniów ze specyficznymi trudnościami w uczeniu się doświadczeniem niekoniecznie pozytywnym. Istnieje zatem obawa, że niechęć do prezentowania siebie na szerszym forum może w przyszłości zaważyć na wyborze kariery zawodowej i osiągnięciu niższego niż oczekiwany statusu społecznego.

Uczniów z dysleksją charakteryzują też częstsze niż ich rówieśników bez dysleksji zachowania konformistyczne oraz odtwórcze, co może wpływać na postrzeganie ich przez otoczenie jako osoby pasywne, zahamowane, cechujące się brakiem wytrwałości, a przez to mniej atrakcyjne towarzysko. To z kolei zapewne przyczynia się do zaniżenia poczucia własnej wartości i pewności siebie - ważnych czynników, zarówno w kształtowaniu się relacji interpersonalnych, jak i w osiąganiu sukcesów edukacyjnych. Na znaczenie wymienionych aspektów w procesie uczenia się uczniów z dysleksją zwracają uwagę N. Humphrey i P.M. Mullins (2002), podkreślając, że uczniowie ci postrzegają siebie jako osoby mniej inteligentne, a tym samym mniej wartościowe od swoich rówieśników bez dysleksji.

Na rolę czynników zewnętrznych w postaci odpowiednio zorganizowanego wsparcia środowiskowego w kształtowaniu u uczniów z dysleksją sposobu myślenia o sobie jako o osobach skutecznych w działaniu, mających poczucie kontroli nad procesem uczenia się, wskazują R. Burden i J. Burdett (2005). Zatem można wnioskować, że kształtowanie odpowiednich relacji w środowisku może być w przypadku uczniów z dysleksją czynnikiem zarówno determinującym rozwój kompetencji społeczno-emocjonalnych, jak i aktywizującym aktywność twórczą w rozwiązywaniu problemów, zarówno tych, które wynikają $\mathrm{z}$ interakcji społecznych, jak i tych związanych z uczeniem się.

Powstaje zatem pytanie o rolę środowisk wychowawczych w kształtowaniu emocjonalno-społecznych kompetencji uczniów ze specyficznymi trudnościami w uczeniu się. Czy powinna ona ograniczać się jedynie do dostosowania 
wymagań edukacyjnych? Wyniki badań nie potwierdzają, by tego typu działania były wystarczające. Być może skierowanie uwagi na kształtowanie się sfery emocjonalno-społecznej u uczniów ze specyficznymi trudnościami w uczeniu się przyczyni się do podniesienia efektywności procesu uczenia się.

\section{Bibliografia}

Argyle M. (1999), Psychologia stosunków międzyludzkich, Wydawnictwo Naukowe PWN, Warszawa.

Bogdanowicz M. (2006), Specyficzne trudności w czytaniu i pisaniu, w: G. Krasowicz-Kupis (red.), Dysleksja rozwojowa. Perspektywa psychologiczna, Wydawnictwo HARMONIA, Gdańsk.

Bogdanowicz M., Adryjanek A. (2004), Uczeń z dysleksją w szkole, Wydawnictwo Operon, Gdańsk.

Burden R., Burdett J. (2005), Factors Associated with Successful Learning in Pupils with Dyslexia: a Motivational Analysis, „British Journal of Special Education”, nr 32(2), s. 100-104, DOI: https://doi.org/10.1111/j.0952-3383.2005.00378.x.

Burden R. (2008), Is Dyslexia Necessarily Associated with Negative Feelings of Self-Worth? A Review and Implications for Future Research, „Dyslexia”, nr 14, s. 188-196, DOI: http://dx.doi.org/10.1002/dys.371.

Crombie M.A. (1997), The Effects of Specific Learning Difficulties (Dyslexia) on the Learning of a Foreign Language in School, „Dyslexia”, nr 3, s. 27-47, DOI: http://dx.doi. org/10.1002/(sici)1099-0909(199703)3:1<27::aid-dys43>3.3.co;2-i.

Crombie M.A. (2000), Dyslexia and the Learning of a Foreign Language in School: Where Are We Going?, „Dyslexia”, nr 6, s. 112-123, DOI: http://dx.doi.org/10.1002/(sici)1099-0909(200004/06)6:2<112::aid-dys151>3.3.co;2-4.

Everatt J., Steffert B., Smythe I. (1999), An Eye for the Unusual: Creative Thinking in Dyslexics, „Dyslexia”, nr 5, s. 24-46, DOI: http://dx.doi.org/10.1002/(sici)1099-0909(199903)5:1<28::aid-dys126>3.0.co;2-k.

Everatt J., Weeks S., Brooks P. (2008), Profiles of Strengths and Weaknesses in Dyslexia and Other Learning Difficulties, „Dyslexia”, nr 14, s. 16-41,

DOI: http://dx.doi.org/10.1002/dys.342.

Ganschow L., Sparks R., Schneider E. (1995), Learning a Foreign Language: Challenges for Students with Language Learning Difficulties, „Dyslexia”, nr 1, s. 75-95.

Goleman D. (2012), Inteligencja emocjonalna, Media Rodzina, Poznań. 
Gwernan-Jones R., Burden R.L.(2010), Are They Just Lazy? Student Teachers' Attitudes about Dyslexia, „Dyslexia”, nr 16, s. 66-86, DOI: http://dx.doi.org/10.1002/dys.393.

Humphrey N., Mullins P.M. (2003), Personal Constructs and Attribution for Academic Success and Failure in Dyslexia, „British Journal of Special Education”, nr 29(4), s. 196-203, DOI: https://doi.org/10.1111/1467-8527.00269.

Jaklewicz H., Bogdanowicz M. (1982), Zaburzenia emocjonalne i ich wptyw na ksztaltowanie się niektórych cech osobowości, na podstawie badań katamnestycznych dzieci z dysleksja i dysortografia, ,Zeszyty Naukowe Wydziału Humanistycznego UG. Psychologia", nr 4, s. 19-28.

Jaworowska A., Matczak A. (2008), Kwestionariusz Inteligencji Emocjonalnej INTE N.S. Schutte, J.M. Malouffa. L.E. Hall, D.J. Haggerty'ego, J.T. Cooper, C.J. Goldena, L. Dornheim. Podręcznik, Pracownia Testów Psychologicznych, Warszawa.

Kamińska-Ostęp A., Gulińska H. (2008), Teaching Methods and Aids Assisting Dyslexic Pupils in Learning Chemistry, ,Journal of Baltic Science Education”, nr 1(3), s. 147-154.

Krasowicz-Kupis G. (2003), Język, czytanie i dysleksja, AWH Antoni Dudek, Lublin.

Konarzewski K. (2000), Jak uprawiać badania oświatowe. Metodologia praktyczna, Wydawnictwa Szkolne i Pedagogiczne Spółka Akcyjna, Warszawa.

Martinelli V., Schembri J. ( 2014), Dyslexia, Spatial Awareness and Creativity in Adolescent Boys, „The Psychology of Education Review”, nr 38,2, s. 39-47.

Matczak A. (2012), Kwestionariusz Kompetencji Społecznych KKS. Podręcznik, Pracownia Testów Psychologicznych Polskiego Towarzystwa Psychologicznego, Warszawa.

Mayer J.D., Salovey P. (1999), Czym jest inteligencja emocjonalna?, w: P. Salovey, D.J. Sluyter (red.), Rozwój emocjonalny a inteligencja emocjonalna, Dom Wydawniczy REBIS, Poznań.

Popek S. (2008), Kwestionariusz Twórczego Zachowania KANH, Wydawnictwo Uniwersytetu Marii Curie-Skłodowskiej, Lublin.

Rubacha K. (2012), Metodologia badań nad edukacja, Oficyna Wydawnicza Łośgraf, Warszawa.

Snowling M.J., Hulme Ch. (2011), Evidence-Based Interventions for Reading and Language Difficulties: Creating a Virtuous Circle, „British Journal of Educational Psychology”, nr 81, s. 1-23, DOI: http://dx.doi.org/10.1111/j.2044-8279.2010.02014.x.

Sternberg R.J. (2001), Psychologia poznawcza, Wydawnictwa Szkolne i Pedagogiczne Spółka Akcyjna, Warszawa.

Terras M.M., Thompson L.C., Minnis H. (2009), Dyslexia and Psycho-Social Functioning: 
Agnieszka Dłużniewska, Kamil Kuracki, Bernadetta Kosewska Postawy twórcze...

an Exploratory Study of the Role of Self-Esteem and Understanding, „Dyslexia”, nr 15, s. 304-327, DOI: http://dx.doi.org/10.1002/dys.386.

Wolff U., Lundberg I. (2002), The Prevalence of Dyslexia among Art Students, „Dyslexia”, nr 8, s. 43-42, DOI: http://dx.doi.org/10.1002/dys.211. 